\title{
Applications of human behavioural ecology to sustainable wildlife conservation and use programmes in developing nations
}

\author{
Joel T. Heinen
}

\begin{abstract}
Human behaviour probably evolved within the confines of small social groups whose members were closely related or interacted repeatedly over long periods of time. Patterns of behaviour regarding use of natural resources reflect this. It would appear that humans also tend to perceive as more urgent environmental problems occurring over a relatively short period of time, at relatively local spatial scales, and which affect them directly, rather than those occurring over greater spans of time and space. If so, then conservation strategies may be planned accordingly. This hypothesis is explored in the context of species conservation by the presentation of a country case-study (Nepal) and by a review of selected conservation programmes from several developing nations. There has been a general lack of research efforts that examine the effect of societal scales in this context, and more such efforts are needed to achieve conservation goals.
\end{abstract}

\section{Introduction}

Heinen and Low (1992) and Low and Heinen (1993) presented a general argument on the behavioural ecology of human resource use, and from this made predictions about the types of conservation programmes likely to succeed. Evidence suggests that most human behavioural evolution occurred within the relatively narrow confines of small social groups based on kinship structure and repeated interactions among individuals over long periods of time (see also Cronk, 1991). This suggests that humans would not be expected to engage in actions that benefit a social group if that group includes many unrelated and unknown individuals, such as is the case in many modern nation states. Heinen and Low (1992) suggested that it is, therefore, unrealistic to expect humans to engage in generally altruistic behaviour in the context of resource conservation programmes. Humans are more likely to engage in actions that benefit a group if that group is relatively small and includes genetic relatives and individuals who interact repeatedly (Heinen, 1994; Low and Ridley, 1994).
In small-scale human societies, Heinen and Low (1992) proposed that social incentives of various kinds may be used to promote conservation strategies. In the context of species conservation, these may include mechanisms already in place in societies that have essentially exclusive access to local renewable resources. In such cases, social controls imposed against overharvesting may lead to long-term sustainability with no other incentive, but such controls may break down if the resources become accessible to larger segments of society (see also Ostrom, 1990). For resource depletion issues that occur over large spatial scales, long time spans, and/or impact large segments of society simultaneously, Heinen and Low (1992) suggested that humans are likely to discount them, i.e. to perceive the problem to be of lesser importance than resource depletion that occurs at smaller scales of time or space, and that affects immediate social groups directly (see also Hannon, 1990; Noss, 1992).

Heinen and Low (1992) suggested that conservation problems in which benefits arising from solutions are very diffuse (i.e. national or 
global) and spread out over time, and where costs are highly localized, will be among the most difficult to solve. One such global environmental issue is the human-induced mass extinction presumably already under way (e.g. Ehrlich and Ehrlich, 1981; Myers, 1984, 1990; Wilson, 1988, 1992; Donovan, 1989; Ward, 1994). This is expected to affect societies in many ways in the long term, due to actual and potential productive and consumptive uses of many species (e.g. Plucknett et al., 1987; Johannes, 1989; Oldfield, 1989; Abramovitz, 1991). There has been a great deal of work on technical aspects of applying population ecology and genetics to species conservation in ex situ conservation programmes (e.g. de Boer, 1992; Heywood, 1992) and population viability analyses (Soulé, 1987). While such approaches are necessary, the ideas discussed above suggest that they are incomplete when tackling species conservation issues, because conservation of species and ecosystems frequently involves shortterm costs to stakeholders (Heinen, 1993). Solutions to resource depletion issues at larger scales may, therefore, be addressed most productively through policies that benefit individuals, thus making it in their interests to achieve a conservation goal.

In this paper some implications of this hypothesis are explored. Some studies generally support the above arguments, but there has been little research that has attempted to separate the relative scales of resource depletion that are predicted to be important with regard to the benefit of using either social or economic incentives. There is not wide agreement on the types of programmes that can be effectively implemented. Many institutionalized programmes, such as many national park management plans and IUCN/SSC Action Plans, tend to focus heavily on technical aspects of conservation, and may not give adequate attention to incentive-based mechanisms to help achieve conservation goals. The critical issues to consider with regard to sustainability in the context of species conservation are, therefore: (a) what types of programmes will probably be workable from the standpoint of local people, (b) what types of programmes will probably lead to conflicts, and (c) what types of incentives, at socially relevant scales, can be implemented to ameliorate such conflicts.

\section{Case study: species conservation legislation in Nepal}

Nepal is typical of many developing nations in its history of enactment of conservation legislation. The National Parks and Wildlife Conservation Act of Nepal was passed in 1973 (Heinen and Kattel, 1992). Section 10 gave complete legal protection to Schedule I (endangered) species, which includes many large mammals. No hunting is allowed for Schedule I species, except that stipulated under Section 21, which states that 'man-eating' tigers or 'mad' elephants could be destroyed as could any wild animal in the process of attacking a person or a domestic animal. Aside from this provision, the Act is extremely restrictive with high fines and mandatory jail sentences for the taking of species for which there are illegal external markets, such as musk deer, tiger and rhinoceros.

Schedule II of the Act lists species that can be legally harvested: large and small game mammals, game birds, some pests, and other species for which eggs or products are occasionally collected (e.g. small fur-bearing mammals and turtles). The fees payable for game species are rather high for rural villagers, but a subsequent amendment allows for crop-raiding wild boar to be killed without a licence. Other than these provisions, there is little in the way of affordable and permissible wildlife uses for local people, and there is no financial compensation for people who suffer from crop damage due to wildlife.

Heinen (1993) showed that people living around Kosi Tappu Wildlife Reserve in southeastern Nepal expressed very negative attitudes about the reserve, complaining particularly about the presence of wild buffalo (a Schedule I species), which caused some crop damage. However, the study also showed that people exaggerated those costs. For example, most stated that buffalo caused year-round crop damage throughout the 
region, whereas detailed field surveys showed that most damage occurred in one season and in a restricted area. People frequently complained that buffalo destroyed fences, whereas surveys showed that most damage was caused by people cutting the wires. Nepal and Weber (1993) reported a study on park-people relations around Royal Chitwan National Park in which numerous costs to local residents were documented, as were generally negative attitudes.

Political turmoil throughout Nepal started in 1989 with a trade embargo imposed by the Government of India, and continued into 1990 with the pro-democracy movement that led to governmental reform and reduced powers of the monarchy. With these broader political problems, guards reduced policing of Nepal's parks, and this led to regular poaching of both rhinoceros and tigers in Chitwan National Park - one of Nepal's premier reserves and a World Heritage Site - for the first time since its establishment in 1973 (Martin, 1992).

From these examples, it is apparent that relations between Nepal's reserves and the local people are inadequate for long-term conservation of rare mammals, even in the oldest and one of the best-established reserves. Other extreme cases of park-people conflicts have been documented in many parts of the world (e.g. Deb Roy and Jackson, 1993; Kemf, 1993).

All parks and reserves managed by the Department of National Parks and Wildlife Conservation in Nepal are protected by armed soldiers, but there is very little enforcement of wildlife legislation outside the existing protected-area system (Heinen and Kattel, 1992). This is also true of the situation with regard to enforcement in many other developing countries (Nichols, 1987). The uneven implementation of wildlife legislation in Nepal over the past 20 years has resulted in the population sizes of many species increasing in protected areas, exacerbating conflicts with people who live around them. Poaching occurs outside protected areas (Heinen and Yonzon, 1994), and other illegal uses are common, such as the sale of fur coats made from protected species for tourists (Heinen and Leisure, 1993).
The thesis presented here would suggest that a major problem with regard to wildlife conservation programmes in Nepal and other developing countries is that the people who incur the costs are frequently not those who receive benefits from the programmes. In many developing nations, benefits in the form of income from nature-based tourism goes mainly or solely to relatively wealthy, educated individuals who own lodges and speak at least one European language. This highlights the need for, and the importance of, programmes that allow for at least some extractive uses, compensation in cases in which people incur direct costs such as crop damage caused by large herbivores, and more equitable distribution of profits from tourism (see also Wells, 1992). Nepal has since instituted a buffer zone management amendment to the 1973 Act, currently under implementation, in an attempt to improve park-people relations (HMG, 1992; Sharma and Shaw, 1993).

In this context the key to sustainability lies in designing programmes in which benefits meet or exceed the costs to people who incur them. That others, such as lodge owners, international tour operators, and national treasuries, also receive economic benefits is largely immaterial in the context of sustainability of wildlife conservation programmes. In essence, until such compensatory programmes can be designed and fully implemented within nations that are attempting to conserve important biotic resources, conservation cannot be considered sustainable. Others have suggested a similar agenda for managing renewable resources in developing countries (e.g. McNeely, 1993). The suggestion here is that this is because humans have evolved to perceive and act upon short-term costs and benefits to themselves. If benefits do not exceed perceived short-term costs, programmes are likely to fail. In some cases, local management with no external economic incentive can work, but only under conditions in which relatively small groups of individuals have exclusive access to a resource, and have a stake in sustainable harvest or protection. 
Some case-studies of species protection and use in the developing world

Robinson and Redford (1991) prefaced their volume on use and conservation of wildlife in the Neotropics with the observation that many species are economically important in various market situations at various scales, and that managed exploitation is consistent with conservation of these species. They also suggested that there has been lack of appreciation of this, largely because the Neotropics have been poorly studied, both culturally and biologically. Fortunately, the situation is now being rectified due to the efforts of a growing numbers of research institutions and individuals within and outside the Neotropics.

There is a growing body of evidence that suggests that sustainable use of Neotropical wildlife is possible and is consistent with the overall goals of conserving species and their habitats. Reports by Werner (1991) on farming iguana, Dallmeier (1991) on sport-hunting whistling ducks, and Franklin and Fritz (1991) on commercial uses of the wool of wild guanaco all suggest that species conservation is or could be enhanced along with exploitation. However, this is not the case for all species in all situations. Lagueux (1991) studied the economics of turtle-egg collection in a coastal community in Honduras, and showed that virtually all eggs of the olive ridley sea turtle were harvested in the study area.

Thus, overexploitation of important commercial species is possible and use alone will not necessarily assure conservation success, especially if there are external markets in which individuals can achieve high profit margins and invest money elsewhere (Clark, 1973). Controls and alternatives are needed in many such cases. For example, the Brazilian government has instituted a project to promote the conservation of sea turtles by providing alternative incomes to fishermen who formerly harvested turtle eggs. The Turtle Project (Projeto Tamar), around the coastal town of Bahia, provides full-time salaries to fishermen to protect beaches, collect turtle eggs, and bring them to an artificial hatchery, from which the juveniles are later released
(Swimmer, 1993 and pers. comm.). The project also operates a farm, which provides goats' milk and chicken eggs to fishermen and their families as alternative sources of protein to turtle eggs, and hires local people to make and sell tee-shirts to tourists. This appears to be an excellent example of the kinds of incentives and alternatives to direct harvest that can be offered to local people where use is likely to lead to overexploitation of an animal resource, and it could possibly be repeated elsewhere.

Robinson and Redford (1991) and others further suggest that unless wildlife species are of some use to people, they will not be valued. This viewpoint is perhaps especially relevant to developing nations, where wild species are of great importance in providing protein sources and in causing direct economic losses for rural residents. Bonner (1993) described Zimbabwe's Communal Areas Management Programme for Indigenous Resources (CAMPFIRE), which was first conceived in the 1970s and officially established in 1986 (Mbanefo and De Boerr, 1993). The programme is based on the philosophy that conservation of wildlife is possible through use and compensation in communal areas in which at least some people had been hunting for many centuries. It includes culling edible species such as antelope, allowing big-game hunting on a quota-basis, and compensating for crop damage by destructive species such as elephant and buffalo. Meat hunted in the communal areas can be sold in local markets well below prices for domestically raised meat, and thus rural residents have access to cheap sources of animal protein. This alone is an important incentive considering the levels of malnutrition in several African nations.

There are regular meetings within CAMPFIRE to which citizens can bring grievances about crops or livestock lost to wildlife, and seek just compensation. A recent estimate suggested that one communal area, which has successfully implemented the programme, will earn over \$US 0.5 million per year by the mid 1990s through this approach (Bonner, 1993). Profits can be used by local villages for direct payment to households and investments in community projects, such as schools 
and health posts. Mbanefo and De Boerr (1993) discussed other benefits, but also pointed out that the programme is still evolving and that not all districts have been equally successful in implementation and some have had problems with equitable distribution of profits. Thus there remain obstacles to overcome. The major goal of CAMPFIRE is to devolve control of wildlife resources from the national to the district level, and then down to the level of wards and villages - local control is crucial to its success. Poaching has been markedly reduced in many districts (Mbanefo and De Boerr, 1993), a phenomenon that was also reported for a similar programme in Zambia (Lewis et al., 1990).

Janzen (1992) described several programmes in Costa Rica, one of which focuses on training rural residents as parataxonomists for biodiversity inventories. Wild specimens are collected by rural people who are certified as parataxonomists after they have received training in the scientific preparation of various taxa. Specimens can be presented to any one of Costa Rica's 19 Biodiversity Offices and are subsequently sent to the country's National Biodiversity Institute in San José for scientific classification. Janzen estimated that the parataxonomists are generating hundreds of thousands of prepared specimens per year. This practice will doubtlessly have many positive effects on attitudes about conservation in the rural communities in which the trained parataxonomists live. Such potential for local conservation education is highly worthy of study in its own right.

Plotkin and Famolare (1992) presented a collection of essays on harvest and marketing of products from rain-forest areas. Although there are numerous obstacles to the marketing of non-timber forest products, including issues such as accessibility and economic risks to potential investors (Pendelton, 1992), there is great potential for their sustainable use, which could provide financing for economic incentives for the conservation of rain-forest ecosystems. Salafsky et al. (1993) suggested that plans for extractive reserve management must be designed to take into account a number of sociopolitical factors, such as land tenure, social infrastructure, and marketing mechanisms.

The alternatives to date have been either strict and generally unpopular protection of natural areas and species, which has sometimes included the posting of armed guards (e.g. Nepal), or widespread deforestation (e.g. Brazil, Indonesia). The cases above suggest that conservation through use offers the most promise for conservation as well as for protection of rights and freedoms of local people. Such approaches are predicted to be generally more popular because they will be perceived by local residents as being in their own shortterm, direct interests. If so, public support will render them more likely to be sustained through time with less need for centralized and expensive law-enforcement mechanisms. Incentives may need modification on occasion, especially if people can easily exploit a biotic resource and sell it to larger markets (e.g. seaturtle eggs), but the general approach has both theoretical integrity and empirical backing.

\section{Discussion}

Many people who work in the area of international wildlife conservation believe that if wild species are not valued, they will disappear. Wildlife must, therefore, be used in some way to provide value to local people who incur costs from its presence. Abundant recent field studies from developing countries add credence to this belief. What is proposed here and elsewhere (Heinen and Low, 1992) is a theoretical background for why this appears to be the case; humans and other organisms did not evolve to behave in altruistically in general, and there is no evidence to suggest that they have done so or will begin to do so in the interests of conserving other species, if this involves some perceived or actual cost to themselves. Many economic issues based on the work of McNeely (1998), Dixon and Sherman (1990) and Swanson and Barbier (1992) are highly relevant for planning incentive-based species and protected-area conservation programmes.

The commercialization of wild species has 
not been without detractors. As Rasker et al. (1992) discussed, the most productive approaches to species conservation may be somewhere between complete public ownership and privatization. This is because there are numerous sources of potential market failure, including the fact that private ownership is difficult to assign to some wildlife resources, such as migratory species or other resources that cross political boundaries (Anderson and Leal, 1991). For example, private hunting clubs in the southern USA have the potential for overharvesting wintering waterfowl that breed in the northern USA and Canada, and thus reduce hunting opportunities along major flyways, at little immediate economic loss to themselves.

Clark (1973) showed that the rational economic use of some species in which discount rates are high and growth rates are low (e.g. whales), is to harvest them to extinction and invest the money elsewhere. Thus, in some cases, taxes or other mechanisms that adjust for market failures may be necessary, but the market is expected to function properly if adjustments are properly made and enforced (Aylward, 1992). The role of national governments, or of international conventions in the case of some far-ranging species, is therefore one of enforcer and not proprietor. The other extreme, complete public ownership (if that public is large), frequently has a set of associated problems because there is no value assigned to resources in the first place, and hence no incentive to conserve.

Public ownership (if that public is small) is expected to work if ownership is assigned communally to related and/or repeatedly interacting individuals. In such cases, all individuals have a stake in sustainable management or protection, and any controls imposed against over-harvest can be effective through existing cultural mechanisms, defined by Heinen and Low (1992) as social incentives. Sherpa (1993) described an indigenous forest protection system, enforced by his own ethnic group, in the Sagarmatha (Everest) region of Nepal. This system is thought to have broken down at least partly because all forests were nationalized in Nepal in 1957.
The types of uses for wild species proposed need not be consumptive, although such uses are common in most nations. Revenues from nature-based tourism may be sufficient to provide economic incentives to promote species conservation, and are already quite important to national economies in several of the countries mentioned above (e.g. Costa Rica, Nepal, Zimbabwe). A large influx of tourist dollars in itself is not sufficient. Also necessary are progressive programmes that allow for the distribution of some revenues to local people who suffer costs from the presence of wild species and protected areas. Thus Zimbabwe's CAMPFIRE programme and other such schemes seem to be particularly relevant in this regard.

This argument is not meant to belittle or alienate the minority of (relatively) wealthy residents of the developed world who give some percentage of their disposable incomes voluntarily to wildlife conservation non-governmental organizations (NGOs). Many of these donors are provided with social and economic incentives in the form of certificates and tax exemptions. The fact that many people make such contributions therefore does not disprove the general hypothesis. Furthermore, the 'costs' of conservation to such people are frequently small when donations are calculated as a percentage of total income. The major costs of conservation are incurred by people who have rights removed and suffer economic losses due to the presence of species and land set aside to protect them. The majority of incentive structures, be they social or economic, should thus be focused on people who incur these costs.

In some cases, economic incentives may be necessary if the conservation of a species poses some economic risk to human endeavours. Brazil's Projeto Tamar, Nepal's new attempts at buffer-zone management, and Zimbabwe's CAMPFIRE are particularly relevant here. In many other cases, in which there are no direct economic conflicts resulting from the conservation of a particular species, economic incentives may not be necessary or appropriate. Education and consultation programmes may be all that is needed to provide 
some social incentive for people to go along with conservation programmes. Many NGOs have been innovative in this area through the provision of social incentives, such as those in place to promote recovery of the golden lion tamarin in Brazil (e.g. Kleiman et al., 1990). Janzen's (1992) example of the parataxonomist programme in Costa Rica could also be more fully explored in this context for indirect educational and social benefits it may provide to rural residents.

Soulé and Kohm (1989) presented a list of research priorities for the discipline of conservation biology. As with other such endeavours, the list is concerned with the technical aspects of conservation almost exclusively. I have argued that the balance needs to be reversed. The first priority for conservation of biodiversity, including the preparation of species action plans (McNeely et al., 1990) and park management plans (Hough, 1991) in developing countries, should be to research methodologies that would provide people with social and economic incentives to comply with the conservation agenda. If this is not accomplished, there may be little reason to proceed with the biological agenda because it would have less chance of success. However, if it is accomplished, the necessary biological research and management would be much easier to achieve. At the very least, socioeconomic assessments, public participation and education programmes are needed in all biodiversity conservation projects as a first step.

As Deshmukh (1989) noted, the major problems of conservation are socioeconomic rather than biological and, hence, the role of biologists is more limited than perhaps some of us would like to believe. As argued above and elsewhere (Heinen and Low, 1992; Low and Heinen, 1993), natural selection theory applied to human behavioural evolution represents an important paradigm for understanding why this may be so in the general sense, and also may represent a theoretical framework for understanding key issues of both geographic and temporal scales inherent in solving any number of conservation problems through incentive-based approaches.

\section{Acknowledgements}

John Baden, Alice Clarke, Gus DiZerega, Clare Ginger, Nandita Jain, Bijaya Kattel, Deepak Khatry, Bobbi Low, Jai Mehta, Uday Sharma, Ganga Ram Singh, Sharon Stash, Bishwa Nath Upreti, David White, Pralad Yonzon, and two anonymous referees commented on earlier drafts and ideas expressed. The work was supported by the Earhart Foundation of Ann Arbor, MI; the Foundation for Research in Economics and the Environment of Seattle, WA; the Department of Environmental Studies of Florida International University, Miami; and the School of Natural Resources and Environment of the University of Michigan, Ann Arbor.

\section{References}

Abramovitz, J.N. 1991. Investing in Biological Diversity: US Research and Conservation in Developing Countries. World Resources Institute, Washington, DC.

Anderson, T.L. and Leal, D. 1991. Free Market Environmentalism. Westview Press, Boulder, CO.

Aylward, B. 1992. Appropriating the value of wildlife and wildlands. In Economics for the Wilds: Wildlife, Diversity, and Development (eds. T. M. Swanson and E. B. Barbier), pp. 34-64. Island Press, Washington, DC.

Bonner, R. 1993. At the Hand of Man: Peril and Hope for Africa's Wildlife. Knopf, New York.

Clark, C. 1973. The economics of overexploitation. Science, 181, 630-634.

Cronk, L. 1991. Human behavioural ecology. Ann. Review Anthropology, 20, 25-53.

Dallmeier, F. 1991. Whistling duck as a manageable and sustainable resource in Venezuela: balancing economic costs and benefits. In Neotropical Wildlife Use and Conservation (eds J. G. Robinson and K. H. Redford), pp. 266-287. University of Chicago Press, Chicago.

de Boer, L.E.M. 1992. Ex situ propagation programmes as a contribution to the conservation of biodiversity. In Conservation of Biodiversity for Sustainable Development (eds O. T. Sandlund, K. Hindar and A.H. D. Brown), pp. 214-229. Scandinavian University Press, Oslo.

Deb Roy, S. and Jackson, P. 1993. Mayhem in Manas: the threats to India's wildlife reserves. In Law of the Mother: Protecting Indigenous Peoples in Protected Areas (ed. E. Kemf), pp. 156-161. Sierra Club Books, San Francisco.

Deshmukh, I. 1989. On the limited role of biologists in biological conservation. Conservation Biology, $3(3), 321$.

Dixon, J.A. and Sherman, P.B. 1990. Economics of Protected Areas: A New Look at Benefits and Costs. Island Press, Washington, DC. 
Donovan, S.K. (ed) 1989. Mass Extinctions: Processes and Evidence. Columbia University Press, New York.

Erhlich, P.R. and Erhlich, A.H. 1981. Extinction: The Causes and Consequences of the Disappearance of Species. Random House, New York.

Franklin, W.L. and Fritz, M.A. 1991. Sustained harvest of the Patagonian guanaco: is it possible or too late? In Neotropical Wildlife Use and Conservation (eds J.G. Robinson and K. H. Redford), pp. 317-358. University of Chicago Press, Chicago.

Hannon, B. 1990. Biological time value. Mathematical Biosciences, 100, 115-140.

Heinen, J.T. 1993. Park/people relations in Kosi Tappu Wildlife Reserve, Nepal: a socioeconomic analysis. Environmental Conservation, 20 (1), 25-34.

Heinen, J.T. 1994. Emerging, diverging and converging paradigms for sustainable development. International Journal of Sustainable Development and World Ecology, 1 (1), 22-33.

Heinen, J.T. and Kattel, B. 1992. A review of conservation law in Nepal: past progress and future needs. Environmental Management, 16 (6), 723-733.

Heinen, J.T. and Leisure, B. 1993. A new look at the Himalayan fur trade. Oryx, 27 (4), 231-238.

Heinen, J.T. and Low, B.S. 1992. Human behavioural ecology and environmental conservation. Environmental Conservation, 19 (2), 105-116.

Heinen, J.T. and Yonzon, P.B. 1994. A review of conservation issues and programs in Nepal: from a single-species focus toward biodiversity protection. Mountain Research and Development, 14(1), 61-76.

Heywood, V.H. 1992. Conservation of germplasm of wild plant species. In Conservation of Biodiversity for Sustainable Development (eds O. T. Sandlund, K. Hindar and A.H.D. Brown), pp. 189-203. Scandinavian University Press, Oslo.

HMG. 1992. National Park and Wildlife Conservation Act, 1973, Fourth Amendment (Buffer Zone Management). Nepal Gazette, 43 (15), 35-40.

Hough, J. 1991. Social impact assessment: its role in protected area planning and management. In Resident Peoples and National Parks (eds P. C. West and S. R. Brechin), pp. 274-283. The University of Arizona Press, Tucson.

Janzen, D.H. 1992. A south-north perspective on science in the management, use, and economic development of biodiversity. In Conservation of Biodiversity for Sustainable Development (eds O. T. Sandlund, K. Hindar, and A. H. D. Brown), pp. 27-52. Scandinavian University Press, Oslo.

Johannes, R.E. 1989. Traditional Ecological Knowledge: A Collection of Essays. IUCN, Gland, Switzerland and Cambridge, UK.
Kemf, E. 1993. People in blue: the Tuareg of Niger. In Law of the Mother: Protecting Indigenous Peoples in Protected Areas (ed. E. Kemf), pp. 186-193. Sierra Club Books, San Francisco.

Kleiman, D.G., Beck, B.B., Baker, A.J., Ballou, J.D. Dietz, L. and Dietz, J.M. 1990. The conservation programme for the golden lion tamarin. Endangered Species Update, 8, 82-84.

Lagueux, C.L. 1991. Economic analysis of sea turtle eggs in a coastal community on the Pacific Coast of Honduras. In Neotropical Wildlife Use and Conservation (eds J.G. Robinson and K.H Redford), pp. 136-144. University of Chicago Press, Chicago.

Lewis, D., Kaweche, G.B. and Mwenya, A. 1990. Wildlife conservation outside protected areas lessons from an experiment in Zambia. Conservation Biology, 4 (2), 171-180.

Low, B.S. and Heinen, J.T. 1993. Population, resources, and environment: implications of human behavioural ecology for conservation. Population and Environment, 15 (1), 7-41.

Low, B.S. and Ridley. M. 1994. Why we're not environmentalist altruists - and what we can do about it. Human Ecology Review, 1, 107-136.

Martin, E.B. 1992. The poisoning of rhinos and tigers in Nepal. Oryx, 26, 82-86.

Mbanefo, S. and De Boerr, H. 1993. CAMPFIRE in Zimbabwe. In Law of the Mother: Protecting Indigenous Peoples in Protected Areas (ed. E. Kemf), pp. 81-88. Sierra Club Books, San Francisco.

McNeely, J.A. 1988. Economics and Biological Diversity: Developing and Using Economic Incentives to Conserve Biological Resources. IUCN, Gland, Switzerland and Cambridge, UK.

McNeely, J.A. 1993. People and protected areas: partners in prosperity. In Law of the Mother: Protecting Indigenous Peoples in Protected Areas (ed. E. Kemf), pp. 249-257. Sierra Club Books, San Francisco.

McNeely, J.A., Miller, K.R., Reid, W.V., Mittermeier, R.A. and Werner, T.B. 1990. Conserving the World's Biological Diversity. IUCN Publication Services, Gland, Switzerland.

Myers, N. 1984. The Primary Source. W. W. Norton and $\mathrm{Co}$, London.

Myers, N. 1990. Tropical forests and life on earth. In Lessons from the Rainforest (eds S. Head and R. Heinzman), pp. 13-24. Sierra Club Books, San Francisco.

Nepal, S.K. and Weber, K.E. 1993. Struggle for Existence: Park-People Conflict in Royal Chitwan National Park. Asian Institute for Technology, Bangkok.

Nichols, J. 1987. The Animal Smugglers. Facts on File, New York.

Noss, R.F. 1992. Issues of scale in conservation bio- 
logy. In Conservation Biology: The Theory and Practice of Nature Conservation Preservation and Management (eds P. L. Fielder and S. K. Jain), pp. 239-252. Chapman and Hall, New York.

Oldfield, M.L. 1989. The Value of Conserving Genetic Resources. Sinauer Associates, Sunderland.

Ostrom, E. 1990. Governing the Commons: The Evolution of Institutions for Collective Action. Cambridge University Press, Cambridge.

Pendelton, L.H. 1992. Trouble in paradise: practical obstacles to nontimber forestry in Latin America. In Sustainable Harvest and Marketing of Rain Forest Products (eds. M. Plotkin and L. Famolare), pp. 252-262. Island Press, Washington, DC.

Plotkin, M. and Famolare, L. (eds). 1992. Sustainable Harvest and Marketing of Rain Forest Products. Island Press, Washington.

Plucknett, D.L., Smith, N.J.H., Williams, J.T. and Anishetty, N.M. 1987. Gene Banks and the World's Food. Princeton University Press, Princeton.

Rasker, R., Martin, M.V. and Johnson, R.L. 1992. Economics: theory versus practice in wildlife management. Conservation Biology, 6 (3), 338-349.

Robinson, J.G. and Redford, K.H. (eds). 1991. Neotropical Wildlife Use and Conservation. University of Chicago Press, Chicago.

Salafsky, N., Dugelby, B.L. and Terborgh, J.W. 1993. Can extractive reserves save the rainforest: an ecological and socioeconomic comparison of nontimber forest product extraction systems in Peten, Guatemala, and West Kalimantan, Indonesia. Conservation Biology, 7 (1), 39-52.

Sharma, U.R. and Shaw, W.W. 1993. Role of Nepal's Royal Chitwan National Park in meeting grazing and fodder needs of local people. Environmental Conservation, 20 (2), 139-142.
Sherpa, M.N. 1993. Grass roots in a Himalayan Kingdom. In Law of the Mother: Protecting Indigenous Peoples in Protected Areas (ed. E. Kemf), pp. 45-51. Sierra Club Books, San Francisco.

Soulé, M.E. (ed.) 1987. Viable Populations for Conservation. Cambridge University Press, Cambridge.

Soule, M.E. and Kohm, K.A. 1989. Research Priorities for Conservation Biology. Island Press, Washington.

Swanson, T.M. and Barbier, E.D. (eds). 1992. Economics for the Wilds: Wildlife, Diversity, and Development. Island Press, Washington.

Swimmer, J.Y. 1993. Comparisons of in situ and relocated loggerhead sea turtle nests at Projeto Tamar, Brazil. MSc Thesis, University of Michigan, Ann Arbor.

Ward, P. 1994. The End of Evolution: On Mass Extinctions and the Preservation of Biodiversity. Bantam Books, New York.

Wells, M. 1992. Biodiversity conservation, affluence and poverty: mismatched costs and benefits and efforts to remedy them. Ambio, 21, 237-243.

Werner, D.I. 1991. The rational use of green iguanas. In Neotropical Wildlife Use and Conservation (eds. J. G. Robinson and K.H. Redford), pp. 181-201. University of Chicago Press, Chicago.

Wilson, E.O. (ed.). 1988. Biodiversity. National Academy Press, Washington.

Wilson, E.O. 1992. The Diversity of Life. Harvard University Press, Cambridge.

Joel T.Heinen, College of Arts and Sciences, Department of Environmental Studies, Florida International University, University Park, Miami, FL 33199, USA. 